This is the author's manuscript for publication. The publisher-formatted version may be available through the publisher's web site or your institution's library.

\title{
Solar powered charge stations for electric vehicles
}

Erica Goldin, Larry Erickson, Bala Natarajan, Gary Brase, Anil Pahwa

\section{How to cite this manuscript}

If you make reference to this version of the manuscript, use the following information:

Goldin, E., Erickson, L., Natarajan, B., Brase, G., \& Pahwa, A. (2014). Solar powered charge stations for electric vehicles. Retrieved from http://krex.ksu.edu

\section{Published Version Information}

Citation: Goldin, E., Erickson, L., Natarajan, B., Brase, G., \& Pahwa, A. (2014). Solar powered charge stations for electric vehicles. Environmental Progress \& Sustainable Energy, 33(4), 1298-1308.

Copyright: (C) 2013 American Institute of Chemical Engineers

Digital Object Identifier (DOI): doi:10.1002/ep.11898

Publisher's Link: http://onlinelibrary.wiley.com/doi/10.1002/ep.11898/abstract

This item was retrieved from the K-State Research Exchange (K-REx), the institutional repository of Kansas State University. K-REx is available at http://krex.ksu.edu 


\title{
Solar Powered Charge Stations for Electric Vehicles
}

\author{
Erica Goldin $^{\text {a }}$, Larry Erickson ${ }^{\mathrm{a}}$, Bala Natarajan ${ }^{\mathrm{b}}$, Gary Brase ${ }^{\mathrm{c}}$, Anil Pahwa \\ ${ }^{\text {a } D e p a r t m e n t ~ o f ~ C h e m i c a l ~ E n g i n e e r i n g, ~ K a n s a s ~ S t a t e ~ U n i v e r s i t y, ~ M a n h a t t a n, ~ K S ~} 66506$ \\ ${ }^{b}$ Department of Electrical and Computer Engineering, Kansas State University, Manhattan, KS 66506 \\ ${ }^{c}$ Department of Psychological Sciences, Kansas State University, Manhattan, KS 66506
}

Erica Goldin present address and e-mail: 1113 Nickel Way, Amherst, NY 14228, elgoldin@buffalo.edu

Corresponding Author:

Larry Erickson

1012 Durland Hall

$785-532-4313$

lerick@ksu.edu

Keywords: air quality, greenhouse gas, alternative energy, climate change, energy policy

\begin{abstract}
Every hour, the sun emits more energy onto the Earth's surface than our entire world population uses in one year. [1] Solar power provides us with the possibility of a cleaner and more renewable future. Global climate change as a result of greenhouse gases and the effects of low air quality caused by pollutants have become very substantial issues in our world today. The costs associated with greenhouse gas and air pollutant emissions, and the effect they have on human lives and human health, are major and growing concerns. The development and installation of solar powered charging stations will reduce the amount of greenhouse gases emitted into the atmosphere, future costs associated with climate change, and health issues. Thus, there is environmental, social, and economic value associated with the installation of solar powered charge stations. Solar powered charging stations have the potential of significantly reducing air pollutants and improving urban air quality. The electrification of transportation and the use of solar powered charging stations as an electricity source will improve people's quality of life.
\end{abstract}

\section{Environmental Aspects}

"Solar energy is a responsible, dependable, and renewable energy choice." [2] As the cost to manufacture and install solar panels decreases there is an increasing drive towards solar energy. PV installations were twelve percent of the new electric generation capacity in 2012. In places like Hawaii, where the electric rate is about $\$ 0.30 / \mathrm{kWh}$ and there is plenty of solar insolation, solar energy is an extremely viable option. [3]

Greater utilization of renewable and alternative energies will result in a reduction of the percentage of greenhouse gas emissions. [4] Approximately 16,000 pounds ( $7257 \mathrm{~kg}$ ) of carbon dioxide emissions are created annually by the average household in the United States as a result of electricity usage. However, that number can be reduced by 9,000 pounds $(4082 \mathrm{~kg}$ ) every year with the installation of a typical five kilowatt home solar energy system. [2] The manufacturing and production of solar panels generates far less air pollutants and greenhouse gases than conventional fossil fuel burning power plants. [5] However, there seems to be some concern about the benefits of solar energy considering the fact that 
the manufacturing of solar panels potentially requires toxic heavy metals and results in the emission of greenhouse gases. Since coal and oil also use and release heavy metals during combustion and produce greenhouse gases, researchers have found that if people exchange conventional fossil fuel burning power plants for solar cells, air pollution would be reduced by about ninety percent. [5] Even if one of the worst heavy metals, cadmium telluride, which also happens to be one of the most promising PV technologies, is used to produce solar panels, the toxic emissions would still be reduced significantly when compared to a coal fired power plant. [6] The emissions of cadmium during a cadmium telluride module life cycle are about 0.02 grams of cadmium per gigawatt hour while the cadmium emissions from coal fired power plants are around two to seven grams of cadmium per gigawatt hour. Even though manufacturing of solar panels does result in carbon dioxide emissions, the solar panels will actually become carbon negative after about two years and usually have a lifetime that lasts longer than twenty years. [2] An investigation of cadmium telluride PV modules resulted in estimates of 24 grams of carbon dioxide equivalent per kilowatt hour produced by the module and an estimated energy payback time of a little over one year. Solar power technology provides the advantage of inhibiting the emission of greenhouse gases, heavy metals, and other pollutants that are harmful to the health of humans and the environment. [6]

Road transport is a major source of multiple noxious emissions. Over 85 percent of the greenhouse gases in the transport sector are due to emissions from road vehicles. [7] Each conventional gasoline vehicle releases over a yearly average of four tons of greenhouse gases into the atmosphere. [8] The use of electric vehicles over gasoline powered vehicles seems to be a growing trend among vehicle owners. However, some believe that plug-in electric vehicles could actually worsen the air quality in certain areas taking harmful emissions away from the tailpipe of vehicles and transferring it to the stack of the power plants producing the electricity. Others believe that the decrease in vehicle emissions outweighs the pollution caused by electricity generation. [9] With solar powered charging stations, this is no longer an issue. Once installed, a solar powered charging station emits virtually no greenhouse gases or pollutants. The way in which the electricity that supplies the charging station is produced determines the environmental footprint of electric vehicles. [10]

Using data for an electric power grid, a study found that the emissions for a conventional vehicle, a plug-in hybrid vehicle, and an all-electric vehicle during a 100 mile $(161 \mathrm{~km})$ trip are 87 pounds $(39 \mathrm{~kg})$ of carbon dioxide equivalent, 62 pounds $(28 \mathrm{~kg}$ ) of carbon dioxide equivalent, and 54 pounds $(24.5 \mathrm{~kg}) \mathrm{of}$ carbon dioxide equivalent respectively. [11] Since an all-electric vehicle releases no tailpipe emissions, the carbon dioxide equivalent caused by the use of an all-electric vehicle is based on the source of the electricity powering the vehicle. If an all-electric vehicle is powered by a solar powered charging station, it could virtually become a zero emissions vehicle. Also, a plug-in hybrid electric vehicle does not release any tailpipe emissions while it is running on electricity, so if it is charged using a solar powered charging station its carbon dioxide equivalent emissions for a portion of its trip would be zero. Another study showed that a battery electric vehicle powered with a mix of 27 percent nuclear, 20 percent renewables, and 53 percent fossil fuels would have total carbon dioxide equivalent emissions of 67 to 84 grams per kilometer. A battery electric vehicle powered by electricity produced from coal would release a total of 126 to 155 grams of carbon dioxide equivalent emissions per kilometer. A battery electric vehicle that uses electricity produced by 50 percent wind and 50 percent photo voltaic would release a total of zero to four grams of carbon dioxide equivalent emissions per kilometer. In the extreme case in which a battery electric vehicle is powered by electricity produced entirely by coal or oil, the vehicle would have climate impacts resembling that of a diesel vehicle. [7] Another way to evaluate this situation is to look at the air 
pollutants released by a battery electric vehicle during the production of electricity used for the vehicle and during the use of the vehicle over its lifetime. Overall, a total of about $95 \mathrm{~kg}$ of pollutant are emitted during these two stages. However, about four percent of the total pollutants come from the use of the vehicle as a result of PM10 and PM2.5 being released due to brake and tire wear while the vehicle is in motion. [12] If the production of electricity for this battery electric vehicle is done by the use of a solar powered charging station, the grams of pollutant emitted by the vehicle could be reduced by about 96 percent. As a real-world example, a solar powered charging station, generating five kilowatts of power, has been installed in Lansing, Michigan. The city believes that this charging station will diminish greenhouse gas emissions by more than 115 tons and power over 300,000 miles $(482,781 \mathrm{~km})$ of clean driving. [13]

The transition from conventional gasoline powered vehicles to electric vehicles and the use of solar powered charging stations to power these vehicles will benefit both humans and the environment. Vehicle pollutants have been linked to severe health effects, including respiratory and cardio-pulmonary diseases and lung cancer. [7] Investigators have found that an increase in the concentration of air pollutants that are associated with vehicle emissions increases the risk of heart attacks and strokes. Also, combustion engines release small particulates that can promote vascular effects. [14] According to the World Health Organization, the emissions from car exhausts are responsible for more deaths than road accidents. [7] There are considerable public health values associated with the reduction of vehicle emissions and there are also multiple health costs in terms of life and health care costs caused by air pollution. A life cycle analysis shows that health emission costs for an electric vehicle powered by electricity produced by a coal fired power plant are five thousand dollars during the lifetime of the electric vehicle. [14]

One of the main reasons people shy away from purchasing an electric vehicle is due to a lack of charging infrastructure. By installing a sufficient number of solar powered charging stations, people will be more likely to purchase electric vehicles over conventional gasoline vehicles. Decreasing the number of gasoline vehicles on the road will improve human health and result in less vehicle pollutant caused health effects, and decreasing the reliance of vehicles on coal fired power plants will also have a positive impact on air quality. The health of citizens is dependent on the air quality being in compliance with federal quality standards, and there is a cost associated if air quality regulations are not met. [15] If an area does not meet a certain air quality standard then it is marked as a nonattainment area. If this area does not meet air quality standards in a certain amount of time then that area may face certain consequences such as lawsuits and a loss of federal funding. Areas are often labeled nonattainment as a result of ground level ozone. In the Northeast, vehicle emissions are the major source of nitrogen oxides and volatile organic compounds in the air; these pollutants are responsible for the formation of ground level ozone. [9]

\section{Social Aspects}

There is a very large social value associated with solar powered charging stations. Of course, these charging stations result in multiple social benefits to those who own electric vehicles and charge these vehicles with a solar powered charging station. But the various social benefits associated with the utilization of solar powered charging stations are both direct and indirect ones. Some of the people that benefit from electric vehicles and solar powered charging stations may not even own an electric vehicle. 
Improvements in urban air quality benefit everyone in the urban area. Since every person has different individual values, the benefits one receives from an electric vehicle charged by a solar powered charging station may vary from one person to another.

One of the direct social benefits of a solar powered charging station is shade. The shade produced by the solar panels of the charging infrastructure has a social value associated with it in terms of personal comfort. If one leaves one's car in the shade rather than in the sun, the car will have a significantly cooler internal temperature. For instance, one study in Oklahoma reported that the temperature in a small vehicle dropped from 172 to 111 degrees $\mathrm{F}$ ( 78 to $44 \mathrm{C}$ ) when put into the shade during the day when the temperature was around one hundred degrees F (38 C). High temperatures caused by the sun beating into a vehicle, accompanied with humidity and poor ventilation, can cause harmful effects, including the possibility of a heat stroke, on the body. Along with increasing one's personal comfort, a vehicle shaded by a solar powered charging station will be protected from sun damage which could cause cracked interiors and warped belongings. [16] A car that sits in the sun all day may have a lower trade in value than one that spends its days in the shade. It is possible that solar powered charging stations could provide shade for both plug-in electric vehicles and gasoline vehicles. If there are many more shaded spots then there are plug-in vehicles, gasoline vehicles will have the opportunity to utilize the shaded parking spots as well.

Convenience is a social benefit associated with the use of electric vehicles and solar powered charging stations. A solar powered charging station can provide an electric vehicle owner convenience in many different ways. One who uses a solar powered charging station to power an electric vehicle may receive preferential parking which is especially beneficial in an urban setting where adequate parking may be difficult to come by. Solar powered charging stations also offer convenience to electric vehicle owners in that they can plug in and charge their vehicle almost anywhere they go. There is a value of convenience associated with charging vehicles in the parking spots of locations vehicle owners spend their time instead of having to find and drive to the nearest gas station. Solar powered charging stations may be installed at workplaces, gyms, shopping malls, restaurants, museums, amusement parks, hotels, hospitals, zoos and aquariums, airports, universities, libraries, rest stops on highways, and multiple other public and commercial locations. [17] Along with having convenient charging infrastructure at multiple locations, solar powered charging stations also provide electric vehicle owners with the convenience of not having to wait while their vehicle is being charged. Since some states have banned the locking feature on a gas pump, many gasoline vehicle owners have to bear uncomfortable conditions while pumping gas. Even though it may only take a few minutes to fill up a gas tank, in freezing temperatures this could be distressing. With a solar powered charging station, electric vehicle owners simply have to plug in their vehicle and then are free to go inside.

Consumers have many concerns when it comes to the use of electric vehicles. Some of the major concerns are the availability of charging infrastructure and the suitability of electric vehicles for long trips. [18] This "range anxiety" is a major obstruction to the purchase of electric vehicles. However, as more and more solar powered charging stations are constructed and the network of charging infrastructure grows, consumers will feel more comfortable purchasing electric vehicles. There is a positive feedback loop between the installation of charging infrastructure and the growth of the number of electric vehicles. The construction of solar powered charging stations has a social value in that it diminishes the fears consumers associate with electric vehicles. Since the use of electric vehicles provides even more social 
benefits, installing solar powered charging stations produces indirect social benefits along with direct ones. The use of solar powered charging stations and electric vehicles together will benefit not only the vehicle owners but many others as well.

The installation of solar powered charging stations has another social value of creating local employment and boosting the local economy. The local economy benefits when customers are able to park in the shade and charge their vehicle while they shop, especially if they select a shopping center because of this infrastructure. When compared to other types of energy, solar powered charging stations result in more local employment. For example, the production of petroleum does not often result in the creation of local jobs. If electricity is produced and used locally there is a social value involved. With the construction of a solar powered charging station, local jobs are created to install, maintain, and service the charging infrastructure. There is a significant social value involved with the installation of solar powered charging stations because of more local economic activity in the community.

An improved quality of life caused by better air quality from the use of electric vehicles and solar powered charging stations has a large social value. One of the main benefits of the use of electric vehicles along with solar powered charging stations is reducing human exposure to harmful pollutants including nitrogen dioxide, carbon monoxide, sulfur dioxide, ozone, and particulates. Petroleum based transportation is a major cause of local air pollution in the United States. [19] Populations that are exposed to the air toxins emitted by vehicles have an elevated risk of getting cancer and also may have damage done to their immune, reproductive, neurological, developmental, and respiratory systems. [20] There is also substantial evidence that air pollution provokes respiratory and cardiovascular diseases and leads to premature mortality. [21] Charging an electric vehicle with electricity produced by coal and other non-renewable energy sources may result in the emission of harmful pollutants at the plant in which the electricity is produced. The benefit of using a solar powered charging station to power an electric vehicle is that when the vehicle is running on electricity it is virtually emissions free. Electric vehicles provide social benefits by reducing gasoline combustion. [19] The emission reductions associated with the use of electric vehicles over the use of gasoline vehicles result in benefits in human health related to these emissions. The better air quality results in an overall better human health and a better quality of life. People who live in a community with better air quality are able to enjoy the benefit of living in a more pleasant environment. In urban settings where pollutant levels are particularly high, the use of electric vehicles and solar powered charging stations will have an even greater benefit. [19] Public buses, taxi cabs, and commercial vehicles that are used in urban environments have the potential to be powered electrically using solar powered charge stations. Significantly better air quality can be obtained by changing to electrically powered buses, cabs, and delivery vehicles.

Transportation in the United States is a major contributor to greenhouse gas emissions and greenhouse gases have a major effect on climate change. There seems to be a correlation between greenhouse gasses in the atmosphere and an increase in the severity of weather events. The future impact of climate change is expected to be very large. About one billion dollars was spent in 2011 on twelve severe weather events. [14] These weather events have extreme effects on the populations who experience them. Severe weather events, such as hurricanes and tornadoes, can drastically change people's lives in extremely harmful ways. These weather events not only have high costs associated with them, but they affect the quality of life of those who experience them. There is a significant social value associated with efforts to reduce greenhouse gas emissions and therefore decrease the severity of major weather events. 
The use of electric vehicles with solar powered charging stations will significantly reduce the amount of greenhouse gases that are emitted in the United States and therefore contribute to the lessening of major weather events.

The United States light duty transportation sector is highly dependent on petroleum and a large portion of this petroleum is imported. [19] Being dependent on foreign oil puts the economy of the United States at risk and is also a social justice issue. [22] The United States is susceptible to any volatility in the world oil market based on this dependence. [20] Vehicle owners who drive gasoline vehicles may feel uncertain about the security and unpredictability of the world oil market. Since the use of electric vehicles will reduce or eliminate the need for imported petroleum there is a social value associated with electric vehicle owners not having to worry about the status of the oil supply. Electric vehicles provide owners with the social benefit of increased energy security. Since solar energy is endless, electric vehicle owners who charge their vehicles with solar powered charging stations do not need to have any concern about fuel availability. The high global demand for oil is a component of human rights violations that take place in some countries. [14] "China's efforts to secure foreign oil and natural gas to meet its growing energy demand are contributing to massive human rights violations in Sudan and Burma." [14] The "oil industry in the Niger Delta of Nigeria brought impoverishment, conflict, human rights abuses and despair to the majority of the people in the oil-producing areas." [14] The use of electric vehicles and solar powered charging stations will help bring about energy independence and security and will play a role in the elimination of social injustices taking place in oil-producing nations.

There is a social value associated with the design of an electric vehicle. Electric vehicles provide a quieter ride than gasoline vehicles. In some cities, traffic noise is a major contributor to noise pollution. The quietness of an electric vehicle is a social benefit. Electric vehicles also offer vehicle owners with a smoother ride. A smooth ride has social value because it provides vehicle owners and those who travel in the vehicle a more pleasant and comfortable trip. Since all-electric vehicles are simpler and less expensive to maintain compared to gasoline vehicles there is a social value in owning a vehicle that does not need to be serviced as often and does not require oil changes. [10] An all-electric vehicle has one tenth the parts of the gasoline vehicle and a majority of the parts of a gasoline vehicle that require maintenance are not present in an electric vehicle. These parts include the engine, emissions control systems (including the catalytic converter), muffler, cooling system, electrical generation system and more. As a result of regenerative braking, even the brakes of electric vehicles wear out less quickly than those of gasoline vehicles. Since the battery pack and the electric motor of an electric vehicle do not need to be serviced regularly, the main issues that all-electric vehicle owners need to worry about are normal tire care and the wiper blades. [23] One study found that electric vehicles may save the average vehicle owner 46 percent in annual maintenance costs due to the cleaner and more streamlined system under the hood. [24]

The installation of solar powered charging stations in public locations has social value in that it will encourage the public in green practices. If people are able to see real life examples of green practices on an everyday basis, they may become more accepting of the idea of harnessing solar power for energy and using this energy to power electric vehicles. Seeing the charging infrastructure daily will make the whole idea more realistic to the public. [16]

Individuals who purchase an electric vehicle and use a solar powered charging station will benefit from the fact that they are making a positive contribution to the environment and also helping in the 
advancement of a beneficial technology. [15] Another social benefit is that using a solar powered charging station to power an electric vehicle will display an individual's dedication to a cleaner and healthier environment. One report showed that half of all consumers believe it is very important to show their commitment to the environment through the purchase of an electric vehicle. Many people view owning an electric vehicle as a value statement. [25]

Purchasing an electric vehicle and charging it with a solar powered charging station helps to improve the quality of the environment, reduce pollution, and promote energy independence along with many other things. Those who place a greater overall importance on these various social benefits are more likely to purchase an electric vehicle. [18] Due to the fact that individual consumers have different social values, those who purchase an electric vehicle will experience differing social benefits from their purchase. For those who value a sense of accomplishment, the technological achievements of the system may be the reason they purchase an electric vehicle. An individual who values security may purchase an electric vehicle because of its social value of separating consumers from the risky foreign sources of fuel. Another value some individuals may favor is the value of self-respect. If an individual purchases an electric vehicle and charges it with a solar powered charging station, that individual may respect his or herself for the positive contribution to the environment. On the other hand, an individual who values being well respected may adopt this technology to gain the respect of the surrounding community. The unique personal values of those who purchase an electric vehicle and use solar powered charging stations will determine the various social benefits that these individuals receive. [26]

\section{Social Aspects Matrix}

A matrix was created to investigate how well different vehicles satisfy various social criteria. The alternatives include a battery electric vehicle (BEV) charged with a solar powered charge station, a battery electric vehicle charged with a conventional charging station, a conventional vehicle (CV), a plugin hybrid electric vehicle (PHEV) that charges with a solar powered charge station, a plug-in hybrid electric vehicle that charges with a conventional charge station, and a hybrid electric vehicle (HEV). Each alternative is given a number between 0 and 1 based on how well it satisfies each social aspect. For example, an all-electric vehicle charged with a solar powered charge station is given a 1 for the social aspect of climate change because of its small contribution to global warming and climate change. Each social aspect is weighted differently based on the individual's personal values. A short survey was created asking participants to rank each social aspect based on what they believed was most important. There were around 25 people who participated in the survey including students participating in a research program for the summer, faculty from Kansas State University, and others from the public. Participants were asked to give the aspect they felt was most important a ranking of 1 and the ranking they felt was the least important a ranking of 10 . The most important aspect is given a weighting of 0.20 , the second and third most important are given a weighting of 0.15 , the next two most important are given a weighting of 0.10 , the next two are given 0.08 , the next two are given 0.05 , and the least important aspect is given a weighting of 0.04 . The rankings of each participant were averaged to give each aspect an overall average ranking and weighting. Climate change and range anxiety have the highest mean rankings in Table 1. Convenience is ranked higher than shade.

Table 1 shows the mean ranking, 95\% confidence interval, lowest ranking (least important), highest ranking (most important), and weighting given to each social aspect after each participants 
response was averaged. The result of this matrix (see Table 2) is that the solar powered charge station and the all-electric vehicle are the best alternative and the conventional vehicle is the worst alternative. This result was seen in each individual participants matrix as well as being seen in the matrix of the average values.

Table 1. Average ranking/weighting of social values table: Each social aspect was given a ranking between 1 and 10 by survey participants. The lowest and highest ranking is shown along with the average ranking and $95 \%$ confidence interval in parentheses based on all participant responses. The weight given to each social aspect in this table is based off the mean ranking of the aspect. The social aspect with the highest ranking (corresponding to the lowest number) is given the highest weighting and the social aspect with the lowest ranking (corresponding to the highest number) is given the lowest weighting.

\begin{tabular}{|l|l|l|l|l|}
\hline Social Aspect & Mean Ranking & Lowest Ranking & Highest Ranking & Weight in Matrix \\
\hline Shade & $7.407(3.94,10)$ & 10 & 4 & 0.05 \\
\hline Convenience & $4.370(1,8.76)$ & 8 & 1 & 0.10 \\
\hline Range Anxiety & $3.667(1,7.84)$ & 10 & 1 & 0.15 \\
\hline Employment & $6.519(2.4,10)$ & 10 & 2 & 0.08 \\
\hline Air Quality & $4.222(1,8.81)$ & 10 & 2 & 0.10 \\
\hline Climate Change & $3.111(1,8.05)$ & 10 & 1 & 0.20 \\
\hline Energy Security & $3.889(1,7.69)$ & 8 & 1 & 0.15 \\
\hline Noise Pollution & $8.037(5.22,10)$ & 10 & 4 & 0.04 \\
\hline Maintenance & $6.222(1.19,10)$ & 10 & 1 & 0.08 \\
\hline Value Statement & $7.556(3.07,10)$ & 10 & 4 & 0.05 \\
\hline
\end{tabular}

Table 2. Social Value Matrix: The weightings for this matrix are based on the average rankings of each social aspect shown in Table 1. The battery electric vehicle charged with a solar powered charge station is the best alternative with an overall satisfaction of 0.88 . The conventional vehicle is the worst alternative with an overall satisfaction of 0.34 .

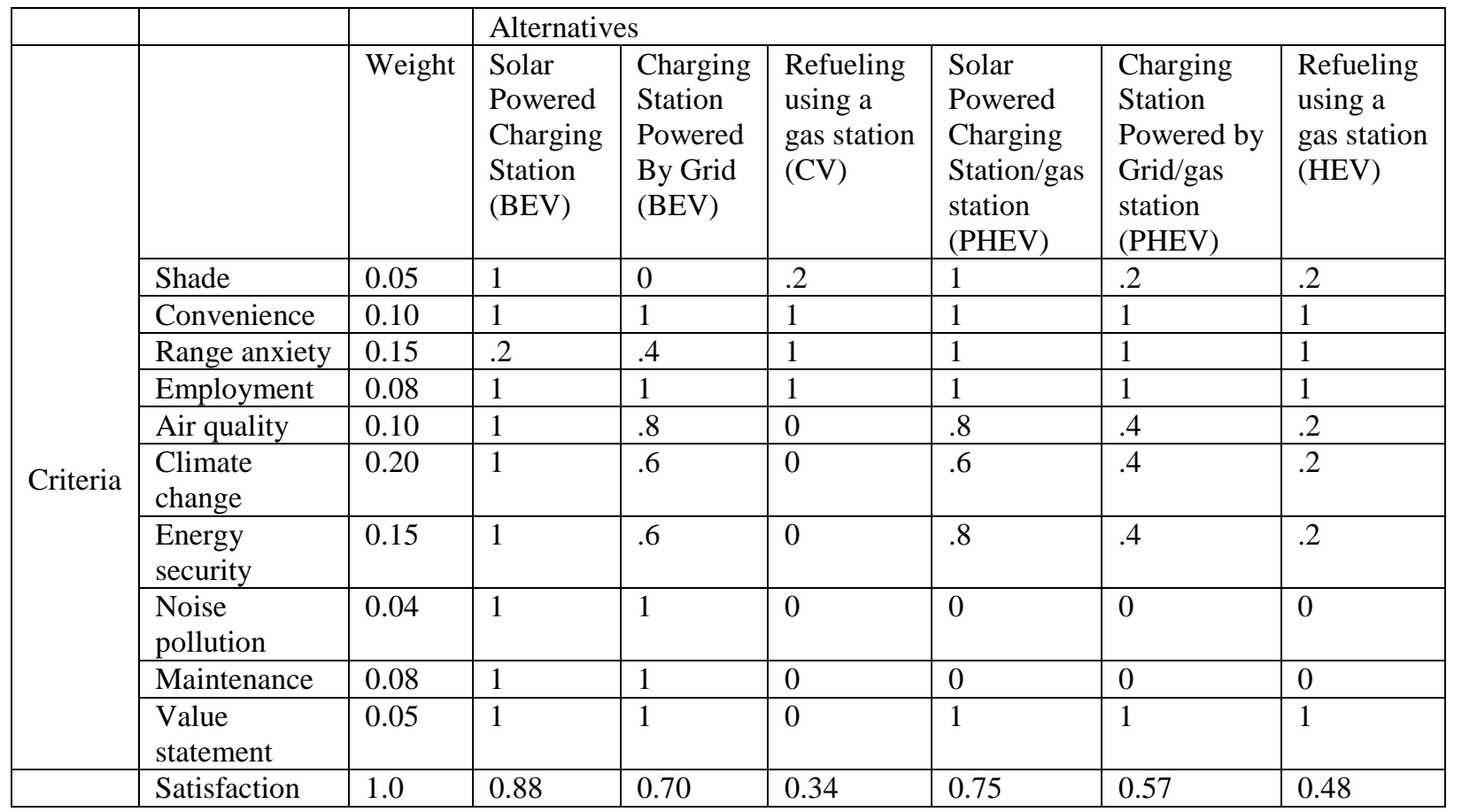




\section{Economic Aspects}

The United States high dependence on foreign oil and the continued consumption of this finite resource has resulted in high gasoline prices. There is value associated with reducing the United States demand for oil in the transportation sector. A decreased reliance on foreign oil is beneficial in that it could reduce future price increases and would also reduce the security concerns associated with United States dependence on foreign oil sources. Since we are dependent on unstable oil producing nations, any attempt of a foreign power to take control of the oil producing nations would put our supply in serious risk. The cost of our dependence on oil has been estimated to be over $\$ 500$ billion per year and military costs associated with the Persian Gulf have also been estimated to be about another $\$ 500$ billion per year. [14]

Electric vehicles are an emerging technology and seem to be one of the best ways for the United States to consume less oil. There is a growing trend in the purchase of electric vehicles in the United States. In 2011 17,080 electric vehicles were sold, in 2012 a total of 52,581 electric vehicles were sold, and as of June 2013 40,647 electric vehicles have been sold. [27] It is clear that the number of electric vehicles on the road is rising. In May 2013 sales of the allelectric Nissan Leaf were up 319.2 percent compared to last year. [28] The price of electricity in the United States is typically one fourth to one half the price of gasoline when the two prices are compared on a per distance traveled basis. [20] Electricity prices are regulated and very steady while gasoline prices are much more unpredictable and can change relatively quickly. [30] Even

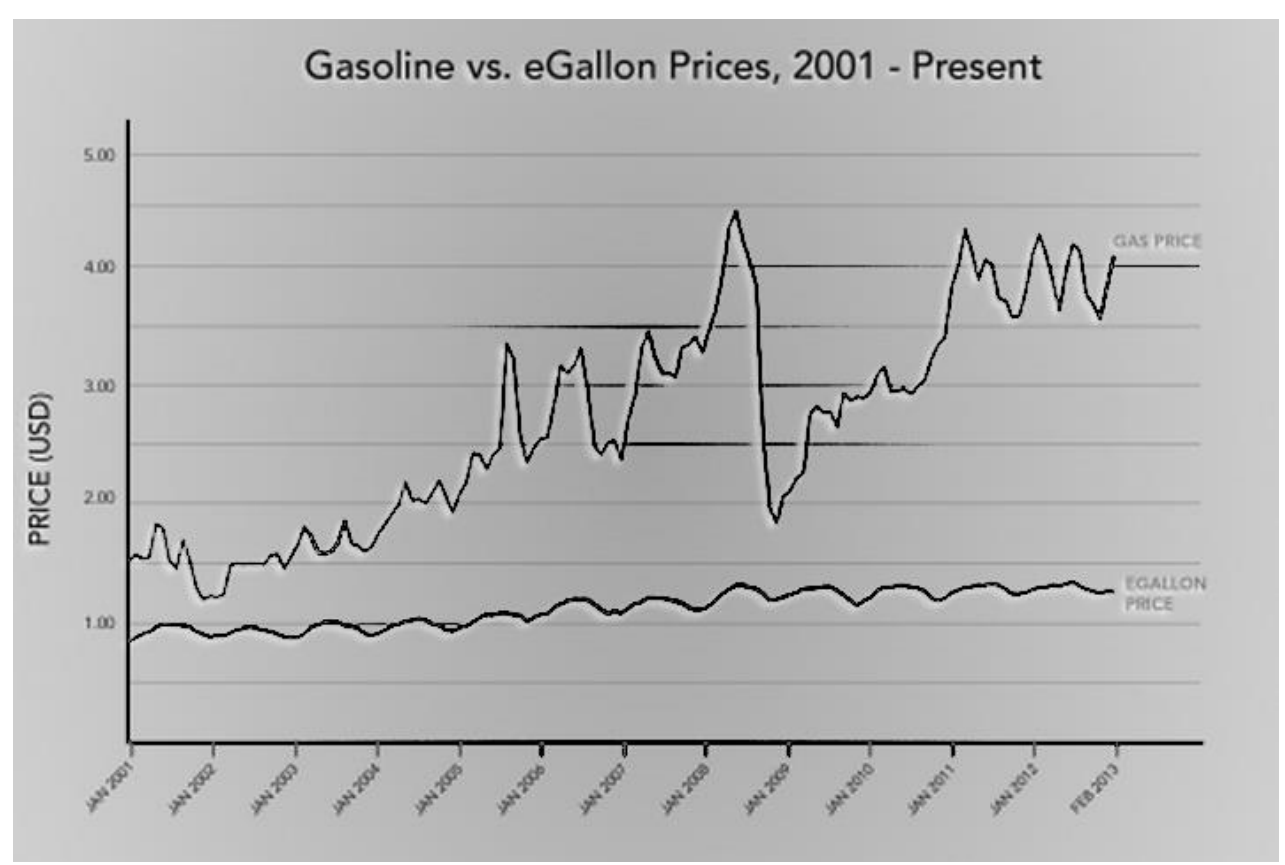

Figure (1): The price of gasoline is much more unpredictable than the price of electricity in the United States. The vertical axis represents dollars per gallon and the horizontal axis represents each month of the year since 2001. The price of an egallon represents the cost of driving an electric vehicle the same distance as driving a similar conventional vehicle on a gallon of gasoline. The price of electricity is stable while the price of gasoline spikes up and down erratically. [29]

though the prices of electric vehicles are expected to decline, presently, the prices of electric vehicles are often higher than those of conventional gasoline vehicles. [31] The Emergency Economic Stabilization Act offers a tax credit between $\$ 2500$ and $\$ 7500$, depending on the battery capacity, for those who purchase an electric vehicle. [32] There are some manufacturers of electric vehicles that say that operating an electric vehicle requires $\$ 0.01$ to $\$ 0.02$ per mile ( 0.006 to 0.012 per $\mathrm{km}$ ) compared to the cost of even the most fuel efficient conventional vehicles of $\$ 0.08$ to $\$ 0.10$ per mile ( 0.05 to 0.06 per $\mathrm{km})$. [33] 
Another study found the cost of gasoline to be $\$ 0.20$ per mile (0.12 per km). [34] Electric vehicles offer the most savings for daily commutes and short driving ranges.

To determine whether or not the purchase of an electric vehicle will benefit the consumer economically overtime compared to the purchase of a gasoline vehicle, one must look at the extra cost of purchasing an electric vehicle versus the yearly savings of using electricity to power a vehicle. Multiple comparisons can be done to see if the purchase of an electric vehicle is worth the extra cost overtime. We have chosen to compare a 2013 Honda Accord, 2013 Toyota Camry, 2013 Nissan Leaf, 2013 Ford Focus EV, 2013 Chevy Volt, and a 2013 Plug-In Toyota Prius. The electric vehicles will be compared both with and without the tax credit. We are using a regular gasoline price of $\$ 3.474$ per gallon $(\$ 0.92 / \mathrm{L})$, a premium gasoline price of $\$ 3.818$ per gallon $(\$ 1.0 / \mathrm{L})$, and an electricity rate of $\$ 0.0969$ per $\mathrm{kWh}$. [35][36] Using the prices and efficiency of each vehicle from fueleconomy.gov [37], assuming each vehicle is driven 15,000 miles $(24,139 \mathrm{~km})$ a year, and using the data in Table 3 a rough estimate can be calculated of the cost of operating each vehicle per year. Figure 2 represents how much is spent per year to fuel or charge the vehicle after it is purchased. Figure 3 represents the total amount of money spent on a vehicle over ten years, including the initial cost of buying the vehicle. The amount of money spent on each vehicle is only based on what the cost is to fuel or charge the vehicle, no maintenance costs are included. A study released by the Institute of Automobile Economics found that the maintenance costs for electric vehicles are about 35 percent lower than the costs for comparable conventional vehicles. [38] It is also assumed that electricity and gasoline prices are stable for ten years. However, it is possible that the price of petroleum may increase compared to the price of electricity over a ten year period.

The figures indicate that the initial higher cost of an electric vehicle is paid off during the vehicles lifetime for some of the electric vehicles while some of the higher costs are not offset by electricity prices. Of course, this is an extremely rough estimate of the cost of these vehicles. The cost of fueling or charging a vehicle will vary greatly with individual driving habits. Depending on one's driving habits, the payback time of the electric vehicles seen in Figure 2 could be larger or smaller. One study compared a 2012 Nissan Leaf and a 2012 Hyundai Elantra and found the payback time to be 6 years. It is very clear that fueling an electric vehicle is less expensive than fueling a conventional vehicle but it is not always enough to offset the current price premium of buying an EV. [39]

Table 3. The data from this table is used to calculate the values represented in Figures 2 and 3.

\begin{tabular}{|l|l|l|l|l|}
\hline & $\begin{array}{l}\text { Purchase } \\
\text { Price }\end{array}$ & $\begin{array}{l}\text { Miles per } \\
\text { gallon }\end{array}$ & $\begin{array}{l}\text { Miles per } \\
\mathrm{kWh}\end{array}$ & $\begin{array}{l}\text { Tax } \\
\text { Credit }\end{array}$ \\
\hline $\begin{array}{l}\text { Honda } \\
\text { Accord }\end{array}$ & $\$ 21,680$ & $\begin{array}{l}29 \mathrm{mpg} \\
(12.3 \mathrm{kmpL})\end{array}$ & N/A & N/A \\
\hline $\begin{array}{l}\text { Toyota } \\
\text { Camry }\end{array}$ & $\$ 22,235$ & $\begin{array}{l}28 \mathrm{mpg} \\
(11.9 \mathrm{kmpL})\end{array}$ & N/A & N/A \\
\hline $\begin{array}{l}\text { Nissan } \\
\text { Leaf }\end{array}$ & $\$ 28,800$ & N/A & $\begin{array}{l}29 \mathrm{kWh} / 100 \\
\mathrm{mi}(18 \\
\mathrm{kWh} / 100 \mathrm{~km})\end{array}$ & $\$ 7,500$ \\
\hline $\begin{array}{l}\text { Ford } \\
\text { Focus }\end{array}$ & $\$ 39,200$ & N/A & $\begin{array}{l}32 \mathrm{kWh} / 100 \\
\mathrm{mi}(20 \\
\mathrm{kWh} / 100 \mathrm{~km})\end{array}$ & $\$ 7,500$ \\
\hline $\begin{array}{l}\text { Chevy } \\
\text { Volt }\end{array}$ & $\$ 39,145$ & $\begin{array}{l}37 \mathrm{mpg} \\
(15.7 \mathrm{kmpL})\end{array}$ & $\begin{array}{l}35 \mathrm{kWh} / 100 \\
\mathrm{mi}(22 \\
\mathrm{kWh} / 100 \mathrm{~km})\end{array}$ & $\$ 7,500$ \\
\hline $\begin{array}{l}\text { Plug-In } \\
\text { Toyota } \\
\text { Prius }\end{array}$ & $\$ 32,000$ & $\begin{array}{l}50 \mathrm{mpg} \\
(21.3 \mathrm{kmpL})\end{array}$ & $\begin{array}{l}29 \mathrm{kWh} / 100 \\
\mathrm{mi}(18 \\
\mathrm{kWh} / 100 \mathrm{~km})\end{array}$ & $\$ 2500$ \\
\hline
\end{tabular}




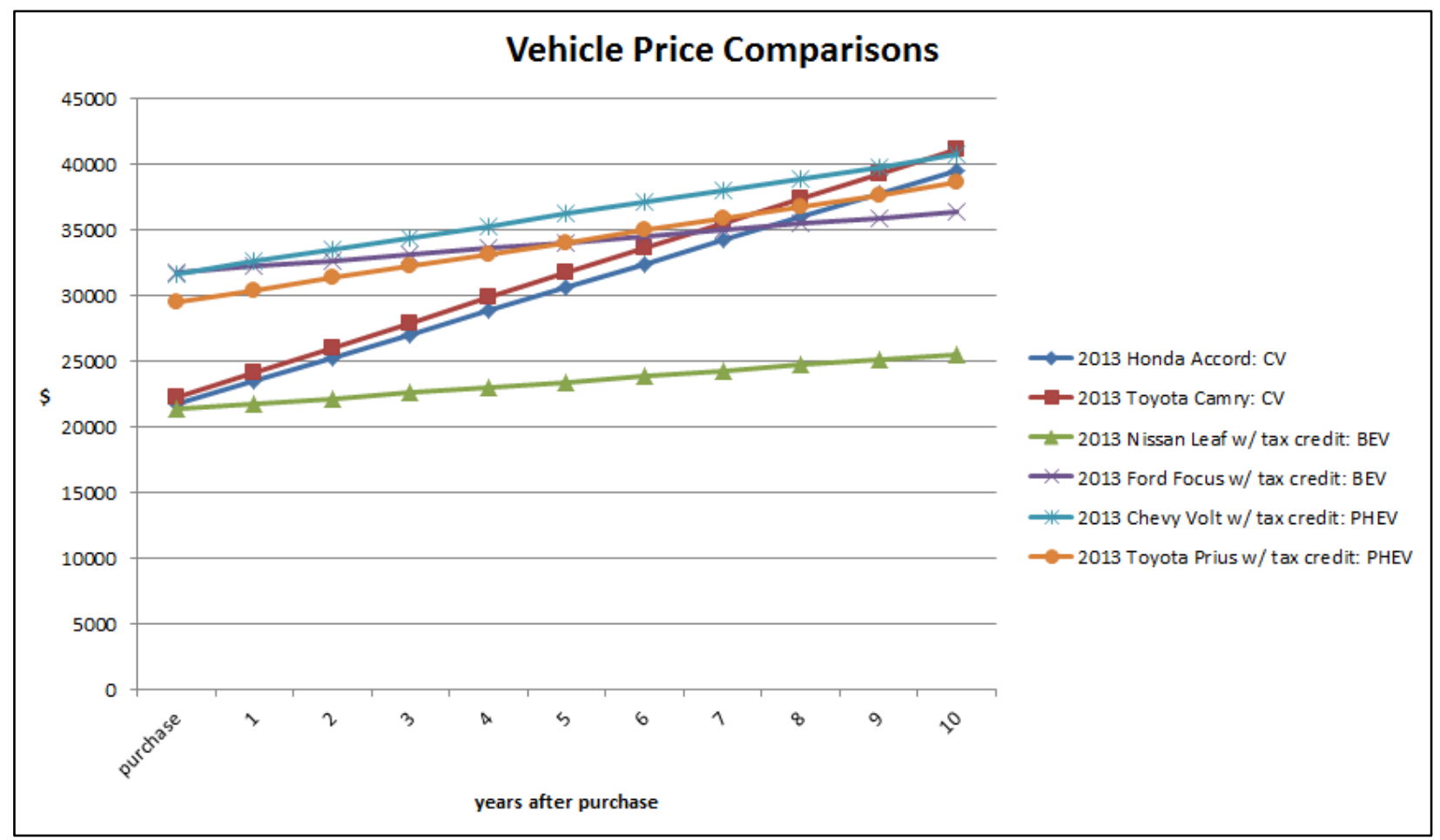

Figure (2): This figure compares the amount of money spent on fueling or charging a vehicle including its initial purchase over a ten year period. The price of regular gasoline is $\$ 3.474 / \mathrm{gal}$ ( $\$ 0.92 / \mathrm{L})$, the price of premium gasoline is $\$ 3.818 / \mathrm{gal}$ $(\$ 1.0 / \mathrm{L})$, and the price of electricity is $\$ 0.0969$ per $\mathrm{kWh}$. Electric vehicles without the tax credit are left out of this figure for clarity. The Toyota Plug-In Prius and the Chevy Volt are driven on electricity about $60 \%$ of the time and are driven on gasoline about $40 \%$ of the time.

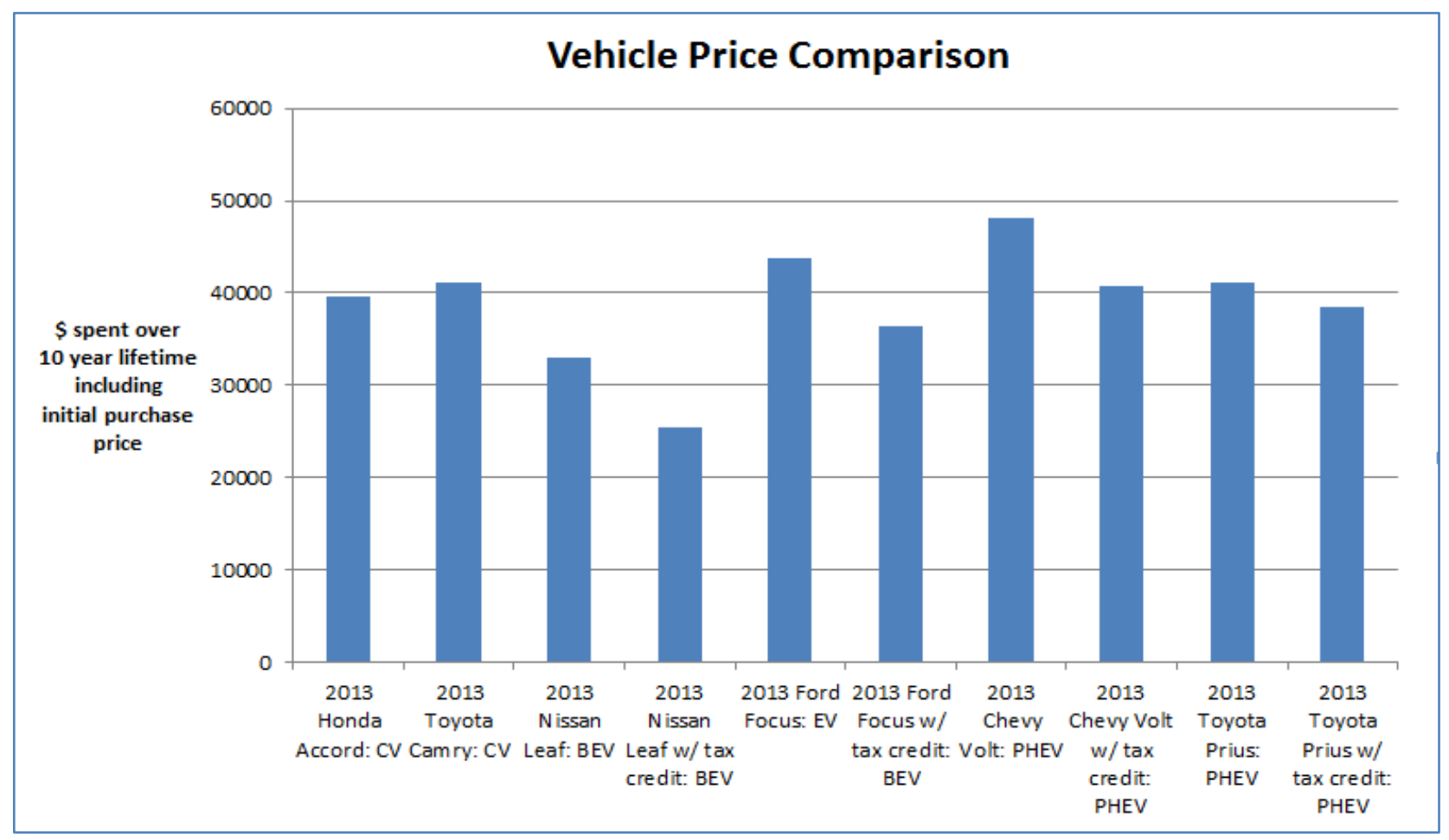

Figure (3): This figure compares the amount of money spent on fueling or charging a vehicle including its initial purchase price based on the number of years after it is purchased. The price of regular gasoline is $\$ 3.474 /$ gal $(\$ 0.92 / \mathrm{L})$, the price of premium gasoline is $\$ 3.818 / \mathrm{gal}(\$ 1.0 / \mathrm{L})$, and the price of electricity is $\$ 0.0969$ per $\mathrm{kWh}$. The Toyota Plug-In Prius and the Chevy Volt are driven on electricity about $60 \%$ of the time and are driven on gasoline about $40 \%$ of the time. 
Along with the cost associated with purchasing and fueling or charging a vehicle, there is also a cost associated with climate change and the release of carbon dioxide into the atmosphere as a result of vehicle use. According to the Department of Energy, the economic impact of the release of carbon dioxide is $\$ 36$ per ton of carbon dioxide. [40] This works out to be about $\$ 0.35$ per gallon $(\$ 0.092 / \mathrm{L})$ of gasoline. Figures 4 and 5 compare the emissions and the economic impact of those emissions of various vehicles over a ten year period. The efficiency of each vehicle is taken from fueleconomy.gov [37] and it is assumed each vehicle is driven 15,000 miles $(24,139 \mathrm{~km})$ per year. According to the United States Energy Information Administration, coal produces 2.15 pounds $(0.975 \mathrm{~kg})$ of carbon dioxide per $\mathrm{kWh}$ and natural gas produces 1.22 pounds $(0.553 \mathrm{~kg})$ of carbon dioxide per $\mathrm{kWh}$. [41] According to the United States Department of Energy the United States national average electricity mix produces 1.58 pounds $(0.717 \mathrm{~kg})$ of carbon dioxide per $\mathrm{kWh}$ and a gallon of gasoline produces 24 pounds of carbon dioxide. [42] These numbers were used to get a rough estimate of the emissions released from vehicles during their use phase over a ten year period.

From the figures one can see that conventional vehicles have a greater amount of carbon dioxide equivalent emissions and consequently a greater economic impact than electric vehicles. An all-electric vehicle powered with a solar powered charging station is the best option because an all-electric vehicle that only uses a solar powered charging station to recharge will not release any greenhouse gases while it is in use and therefore will not have any negative economic impact as a result of greenhouse gas emissions. The economic impact of the gasoline powered Honda Accord is over two thousand dollars greater over a ten year period compared to a solar power charged Nissan Leaf. 


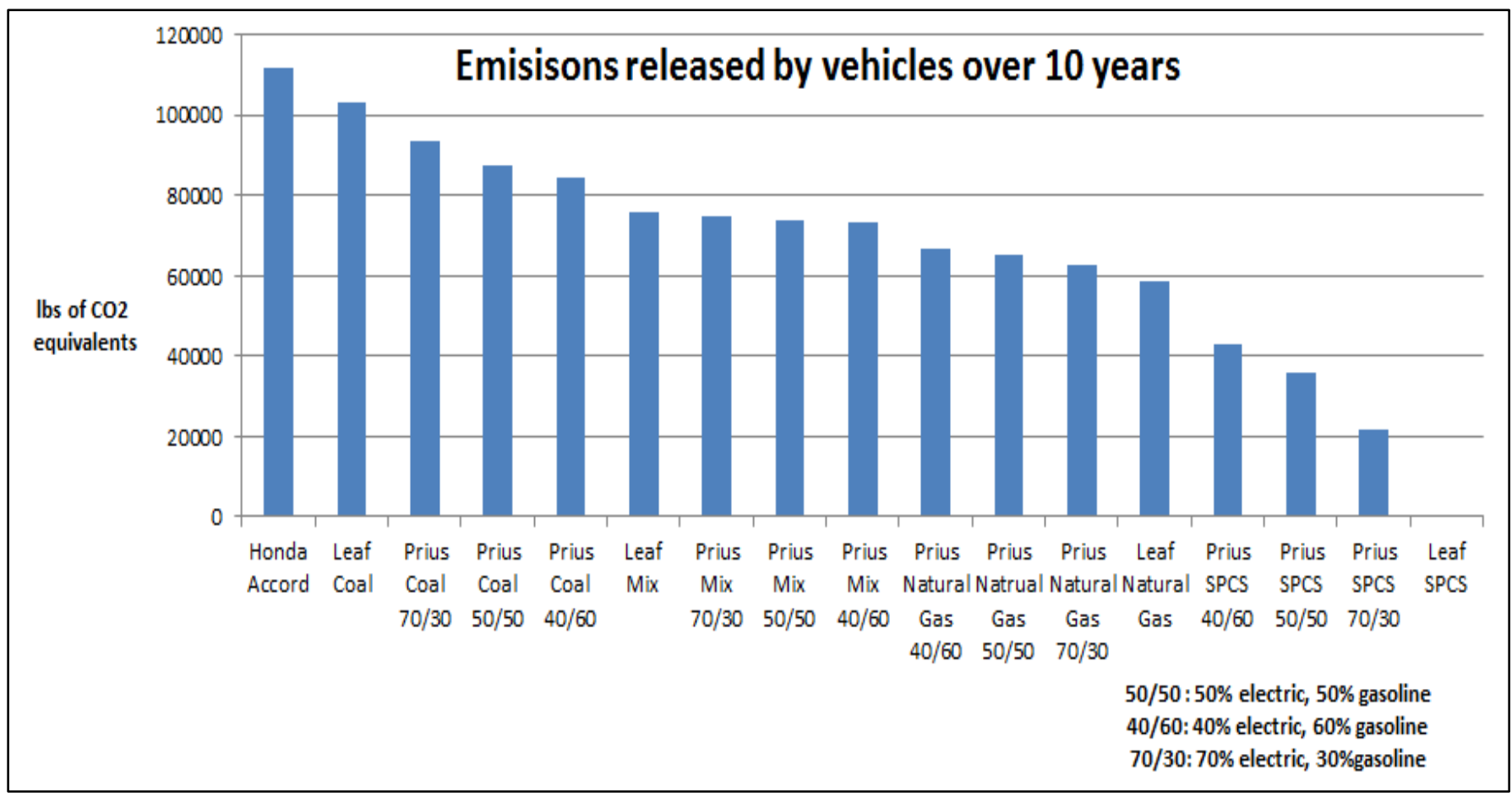

Figure (4): This figure compares the greenhouse gas emissions released by different vehicles during their use phase over a ten year period. Electricity mix represents the United States national average electricity sources. The mix is $49.61 \%$ coal, $19.28 \%$ nuclear, $18.77 \%$ natural gas, $6.50 \%$ hydro, $3.03 \%$ oil, $1.30 \%$ biomass, $0.60 \%$ other fossil, $0.44 \%$ wind. One $\mathrm{kg}=2.2 \mathrm{lbs}$.

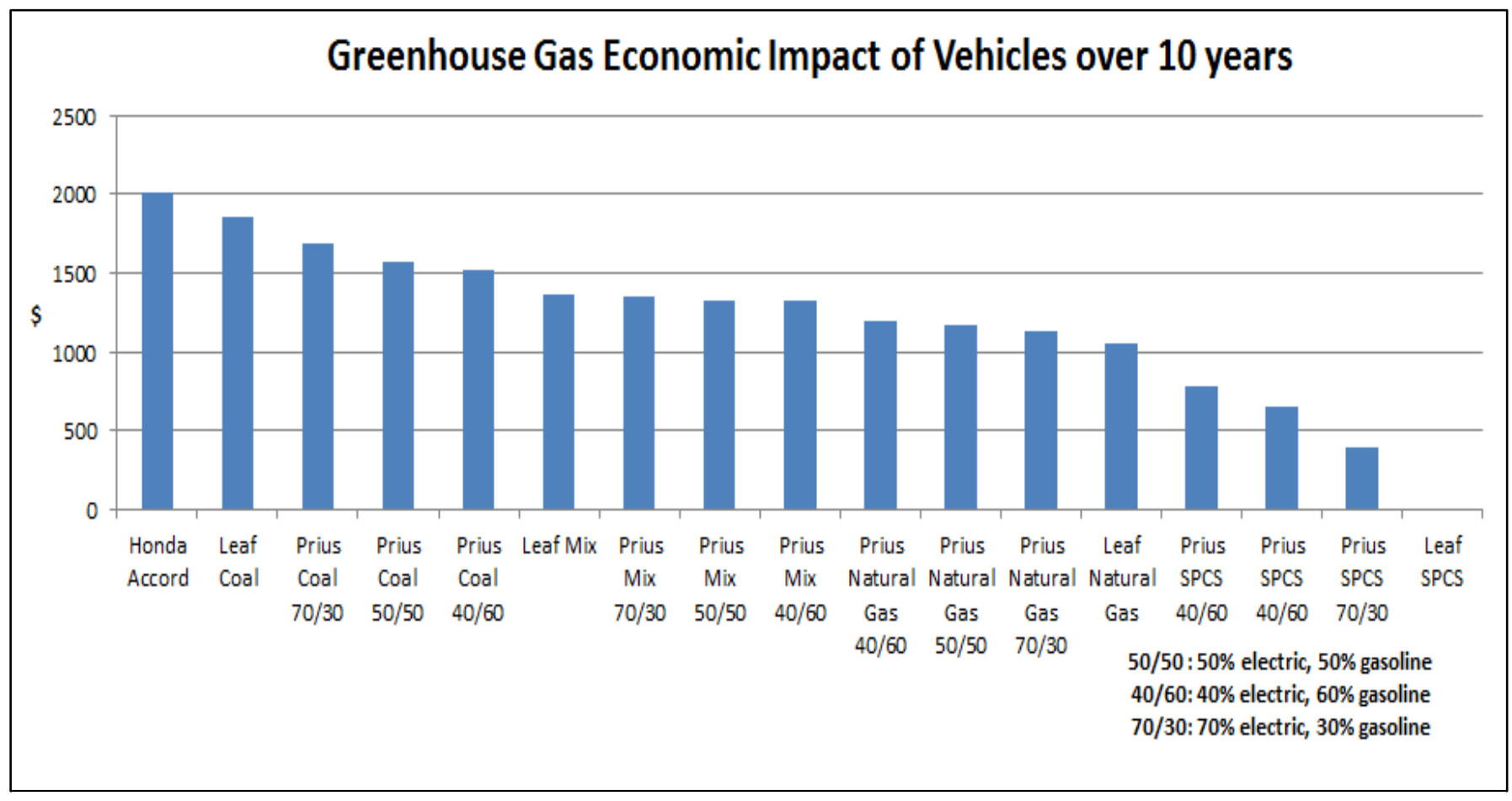

Figure (5): This figure compares the economic impact different vehicles have based on their greenhouse gas emissions. The cost of greenhouse gas emissions is $\$ 36$ per ton. Electricity mix represents the United States national average electricity sources. 


\section{Urban Air Quality}

Transportation is the largest source of air pollution in the United States. A recent study found that in the year 2006 transportation was responsible for half of the carbon monoxide, more than a third of the nitrogen oxides, and about a quarter of the hydrocarbons found in the atmosphere. The pollution released by conventional gasoline vehicles is both primary and secondary pollution. It is primary pollution in that it goes directly into the atmosphere from the vehicle and it is secondary pollution in that the release of these emissions results in chemical reactions between various pollutants within the atmosphere. The main pollutants released by conventional gasoline powered vehicles are particulate matter, hydrocarbons, nitrogen oxides, carbon monoxide, sulfur dioxide, and volatile organic compounds. [43] The level of these various pollutants in the atmosphere is significantly higher in locations that are directly impacted by large amounts of vehicle traffic. [44] Particulate matter can penetrate deep into a person's lungs and cause cancer or other respiratory illnesses and is considered to be the most harmful to human health. Nitrogen oxides are involved in the formation of ground level ozone, can cause lung irritation, and may weaken the body's defense against respiratory infections. When carbon monoxide is inhaled it affects the transport of oxygen throughout the body. Sulfur dioxide forms fine particulates when it reacts in the environment. The volatile organic compounds that are emitted have been linked to serious illnesses such as cancer and birth defects and also react with sunlight to form photochemical smog. [43] Photochemical smog is considered to be one of the largest contributors to urban air pollution in developed countries and is a top concern to those who are working to improve urban air quality. [45] The EPA found that these hazardous air pollutants are responsible for around half of the cancers that are caused by air pollution. [43]

Urban air pollution has become a major factor in the degradation of people's quality of life. A growing body of research has come to the conclusion that either living in or spending significant amounts of time in areas that involve high traffic related air pollution results in health risks. There are many respiratory illnesses and other health consequences, such as asthma, impaired lung function, and adverse birth outcomes, associated with near roadway exposure. [44] A recent study found that 2 million lives every year are lost worldwide as a result of air pollution. [46] Another study found that air pollution is responsible for 1.3 million deaths every year. [47] There is a strong correlation between air pollution and

poor human health. Research in China found that the life expectancy is five and a half years greater in the south than it is in the north due to the fact that those living in the north are exposed to 55 percent higher levels of total suspended particulates in the atmosphere. As a result of this excessive air pollution, residents of northern China collectively lost 2.5 billion years from their lives in the 1990's. [48] It has been found that 350,000 to 400,000 people die prematurely in China each year as a result of outdoor air pollution. [49] In the United Kingdom a study found that poor air quality reduces life expectancy by eight months and causes around 50,000 premature deaths every year. [50]

Due to the fact that road traffic is the main source of air pollutant emissions in urban areas, electric vehicles may play a significant role in decreasing air pollution caused by transportation. Electric vehicles create little or no ozone emissions and produce little or no tailpipe emissions. For these reasons they could greatly improve urban air quality. An introduction of electric vehicles into cities would play a key role in driving down pollution in the most congested and highly populated areas and help to prevent rising pollution levels. [50] Some electric vehicle market penetration scenarios indicate that the use of electric vehicles would result in a reduction of tailpipe air pollutants. [51] The widespread use of electric vehicles may be one of the best ways to reduce air pollutants and emissions related to traffic. 
One problem with electric vehicles is that when they recharge they often use electricity from the grid. A large portion of the electricity that is supplied to the grid comes from non-renewable fossil fuels such as coal or natural gas, which are most commonly used for electricity production. [52] Even though the use of electric vehicles over conventional gasoline powered vehicles would have a positive effect on urban air quality, one study found that the levels of sulfur oxides in the atmosphere would actually increase with the adoption of electric vehicles if there is an increase in the burning of coal in order to produce electricity to charge electric vehicles. [45] Electricity production also results in emissions of nitrous oxide. [52] A positive aspect associated with the adoption of electric vehicles is that even though these vehicles are somewhat reliant on the existing electrical grid, they create much greater flexibility in the power source used for transportation compared to gasoline powered vehicles. Electric power from renewable sources such as wind or solar can be used to charge batteries and thus make wind and solar energy more valuable to consumers. With the adoption of electric vehicles, the use of renewable sources to charge these vehicles can be implemented as a second stage. The use of a solar powered charging station does not release any air pollutants into the atmosphere and is therefore a more beneficial alternative for charging an electric vehicle. If an electric vehicle was charged with a solar powered charging station rather than the electricity from the grid, it would have a much more significant effect on improving air quality and reducing air pollutant emissions.

\section{Solar Powered Charge Stations}

Solar panels can be installed in parking lots to produce electric power and provide shade for parked vehicles. The generated electricity can flow into the electrical grid, and the grid can provide electrical power to charge the batteries of the vehicles. The cost of the installation of the charge station depends on the financial transaction aspects. For example, if there is no charge to the customer or if there is a daily or monthly charge, only an electrical outlet with appropriate voltage and amperage is needed. A charge station with credit card capability is more expensive.

The University of Central Florida installed a solar powered charge station on their campus in January of 2010. In February, the solar panels began feeding power to the main grid on campus. The project took about three months to construct and the total cost of the project was $\$ 380,000$. The entire project was funded by a research grant from the Florida Energy Systems Consortium. Since there is sufficient sunlight in Florida, those who use the solar powered charge station to charge their electric vehicle do not have to pay for the electricity they use unless it exceeds more than $10 \mathrm{kWh}$ of energy. The solar powered charging station provides both a charging outlet and a parking spot for four vehicles. [53] The charging station consists of 48 solar panels and generates about $50 \mathrm{kWh}$ of clean energy per day. Due to the fact that there are not a large number of electric vehicles on the road today, a large portion of the energy produced goes back to the grid and offsets the electricity bill of the university. One interesting aspect of the design of this solar powered charge station is that the solar panels used are bi-facial, meaning that the solar panels can collect thirty percent more power from the light that reflects from the concrete and stainless steel equipment cabinet location beneath the structure. [54]

Two solar powered charging stations were installed in April of 2012 in Como Park in Saint Paul, Minnesota. Each charging station has the ability to charge two vehicles. Those who use the charging stations to charge their vehicles pay one dollar an hour. Each charging station cost $\$ 35,000$ and is eligible for an $\$ 8,910$ rebate from the Xcel Energy Solar Rewards program. Federal stimulus money paid for 
about sixty percent of the project and Xcel Energy and the city of Saint Paul each paid about twenty percent. [55] After the rebate, the cost is about $\$ 13,000$ per vehicle.

Lane Community College in Eugene, OR opened a solar powered charge station in September 2010. The charging infrastructure took 3 months to construct and cost $\$ 800,000$. Lane Community College received a $\$ 100,000$ grant from Eugene Water \& Electric Board and the rest of the project was funded by the community college through bond funds. The solar powered charge station provides eighteen covered parking spaces for charging. [53] The charging station consists of 219 solar panels that are designed to produce around $106 \mathrm{kWh}$ per day. [56]

In February of 2012 a solar powered charge station was installed on the campus of Western Michigan University. The Clean Energy Coalition, which is a nonprofit organization funded by the United States Department of Energy, provided the university with a $\$ 700,000$ grant for the project. The charging stations are available anytime at no cost to those who wish to charge their vehicle. [56] The solar powered charge station consists of fifteen electric vehicle charging stations with an eighteen panel solar array. Coulomb technologies supplied the fifteen level two chargers. The charging infrastructure contains a web-based electric vehicle charging station consumption display. This allows one to look at how many $\mathrm{kWh}$ 's of electricity are produced by the charging station and how many of those kWh go directly to charging vehicles. [58]

One important aspect that must be addressed is the cost of the design and installation of solar powered charge stations. If the cost of installation of a large number of them can be reduced to about $\$ 10,000$ per parking space, many work places, shopping centers, and other establishments will respond and install solar powered charging stations. Where free charging is provided the cost of installation can be reduced. The cost of adding a solar powered charge station in a newly established parking lot will be less than adding one to an existing lot. The cost of $\$ 10,000$ per parking place corresponds to about $\$ 2$ per work day over a twenty year period with about sixteen $\mathrm{kWh}$ produced per day. [14]

\section{Conclusion}

Parking lots provide a great location for solar power to be put into the electrical grid because of the beneficial social values of shade and convenience for vehicle charging. For cases in which the distance to work requires charging in order to drive home electrically, there is significant benefit associated with charging while parked at work. A substantial amount of power can be generated using solar panels in parking lots. The timing of power generation with solar fits well with the needs of workers with electric vehicles and 8:00 to 5:00 employment.

The Nissan Leaf with the solar powered charge station has the lowest cost over 10 years and the lowest greenhouse gas emissions compared to the other alternatives that were investigated. Its impact on urban air quality is also small. Because it has limited range, the opportunity to charge the vehicle at work has significant value.

There are many reasons and benefits associated with moving forward in the installation of solar powered charging stations. The use of solar powered charge stations for electric vehicles has numerous benefits in terms of environmental, social, and economic aspects. Solar powered charge stations and electric vehicles currently do and will continue to benefit society as a whole. 


\section{Acknowledgement}

This research has been partially funded by the National Science Foundation with REU Grant EEC-1166549, and by Black and Veatch.

\section{Literature Cited}

(1) "Solar Fact or Fiction." GreenFuel. Green Fuel, 2013. Web. 1 June 2013. $<$ http://www.greenfuelsolar.com/solar-fact-or-fiction/>.

(2) "Reduce Your Family's Carbon Footprint With Solar Energy." Conergy USA. Conergy, 2011.Web. 1 June 2013. <http://www.conergy.us/desktopdefault.aspx/tabid-148/364_read-592/>.

(3) "U.S. Solar Market and Installation Trends for 2012." 4 June 2013. IREC. Interstate Renewable Energy Council. Web.

(4) "Solar Panels Help Reduce Greenhouse Gas Emissions." Climate 2003. Global Weather News, 10 Apr. 2013. Web. 1 June 2013. <http://www.climate2003.com/?p=13>.

(5) Choi, Charles Q. "Solar Power's Greenhouse Emissions Measured." LiveScience.com. N.p., 26 Feb. 2008. Web. 1 June 2013. <http://www.livescience.com/2324-solar-power- greenhouse-emissions-measured.html>.

(6) Fthenakis, Vasilis M., Hyung C. Kim, and Erik Alsema. Emissions from Photovoltaic Life Cycles. Rep. Environmental Science \& Technology, 4 Jan. 2008. Web. 1 June 2013. <http://pubs.acs.org/doi/pdfplus/10.1021/es071763q>.

(7) Breic, Emma, Carolein Mazal, Gereon Meyer, and Beate Muller, eds. European Roadmap Electrification of Road Transport. Rep. N.p., June 2012. Web. 1 June 2013. <http://www.ertrac.org/pictures/downloadmanager/1/52/electrification_roadmap_june2012_62.pdf>.

(8) "A Carbon Conundrum." American Forests. American Forests, n.d. Web. 1 June 2013. $<\mathrm{http} / / /$ www.americanforests.org/a-carbon-conundrum/>.

(9) Zhu, Charles, and Nick Nigro. "Plug-In Electric Vehicle Deployment in the Northeast." Transportation \& Climate Initiative (2012): Print.

(10) "Electric Vehicles Are Here!" CDD. Community Development Department, 2011. Web. 10 June 2013. <http://www.cambridgema.gov/CDD/Transportation/programs/currentprograms/electricv ehicles.aspx>

(11) "Emissions from Hybrid and Plug-In Electric Vehicles." Alternative Fuels Data Center. U.S. Department of Energy, June 2013. Web. 3 June 2013. <http://www.afdc.energy.gov/vehicles/electric_emissions.php>.

(12) Aguirre, Kimberly, Luke Eisenhardt, Christian Lim, Brittany Nelson, Alex Norring, Peter Slowik, and Nancy Tu. Lifecycle Analysis Comparison of a Battery Electric Vehicle and a Conventional Gasoline Vehicle. Rep. N.p., June 2012. Web. 10 June 2013. <http://www.environment.ucla.edu/media_IOE/files/BatteryElectricVehicleLCA2012-rh-ptd.pdf >.

(13) "First Municipality-Owned Solar Charging Station for EVs Opens in Michigan." Daily Tech. DailyTech, 6 May 2013. Web. 1 June 2013. <http://www.dailytech.com/First+MunicipalityOwned+Solar+Charging+Station+for+EVs+Opens+in+Michigan/article 31492.htm>.

(14) Erickson, L. E., T. Boguski, M. W. Babcock, B. A. Leven, A. Pahwa, G. L. Brase, W. Griswold, K. Kramer, and R. D. Miller. "Community Infrastructure for the Electrification of Transportation." Kansas State University, 2012. Web. 1 June 2013. <http://www.engg.ksu.edu/chsr/files/chsr/sustainability/docs/Electrification-of-Transport-6-22-2012.pdf〉.

(15) Erickson, Larry E. "White Paper on Solar Powered Charge Stations with Shaded Parking."N.p., 27 Feb. 2012. Web. 1 June 2013. <http://www.engg.ksu.edu/chsr/files/chsr/sustainability/docs/WhitePaperSolarPowerChargeStationsShadedParking.pdf $>$.

(16) Erickson, Larry, Dr. "Third Report on the Installation of Shaded Parking Lot Structures with Integrated Photovoltaic Power System at Kansas State University." Kansas State University, 4 Aug. 2011. Web. 1 June 2013. <http://www.engg.ksu.edu/chsr/files/chsr/sustainability/docs/ParkingLot3rdReport2011.p df>.

(17) Nansai, K. "Life-Cycle Analysis of Charging Infrastructure for Electric Vehicles." Applied Energy 70.3 (2001): $251-65$. Print.

(18) Brase, Gary L. "What Would It Take to Get You into This (electric) Vehicle? Consumer Perceptions and Decision Making 
about Electric Vehicles." Kansas State University, n.d. Print.

(19) Skerlos, Steven. "Targeting Plug-in Hybrid Electric Vehicle Policies to Increase Social Benefits." Energy Policy 38.2 (2010): 705-8. <http://www.sciencedirect.com/science/article/pii/S030142150900843X>

(20) "Plug-In Electric Vehicles: A Practical Plan for Progress." School of Public and Environmental Affairs at Indiana University, Feb. 2011. Web. 1 June 2013.

<http://www.indiana.edu/ spea/pubs/TEP_combined.pdf $>$.

(21) Funk, Karina. "Electric Versus Conventional Vehicles: Social Costs and Benefits in France." Transportation research.Part D, Transport and environment 4.6 (1999): 397- 411. Print.

(22) Chan, E., L. E. Erickson, T. K. Boguski, B. A. Leven, and B. Natarajan. "Solar Powered Charge Stations: LCA Thinking." N.p., 2012. Web. 1 June 2013. <http://www.engg.ksu.edu/chsr/files/chsr/sustainability/docs/SolarPowerChargeStations- LCA-Thinking2012.pdf>.

(23) "Electric Vehicle Facts and FAQs." Electric Vehicles. Tom \& Cathy Saxton, 15 Sept. 2012. Web. 2 June 2013. $<$ http://www.saxton.org/EV/evfaq.php>.

(24) "ELECTRIC VEHICLES: MYTHS VS. REALITY." Sierra. The Sierra Club, n.d. Web. 05 July 2013. <http://content.sierraclub.org/evguide/myths-vs-reality>.

(25) Curtin, Richard, Yevgeny Shrago, and Jamie Mikkelsen. "Plug-In Hybrid Electric Vehicles." University of Michigan, 2009. Web. 1 June 2013. <http://www.ns.umich.edu/Releases/2009/Oct09/PHEV_Curtin.pdf>.

(26) Kahle, Lynn. Social Values Segmentation in Marketing Residential Solar Power Installations. 2 Vol. , 2009. Print.

(27) "Monthly Plug-In Sales Scorecard." Inside EVs. N.p., n.d. Web. 16 July 2013. $<$ http://insideevs.com/monthly-plug-in-sales-scorecard/>.

(28) Blanco, Sebastian. "Nissan Leaf Continues Strong Sales Push with 2,138; Chevy Volt Moves 1,607." AutoblogGreen. N.p., 3 June 2013. Web. 15 July 2013. <http://green.autoblog.com/2013/06/03/nissan-leaf-continues-strong-sales-push-with-2-138-chevy-volt-m/> .

(29) Leistikow, Dan. "The EGallon: How Much Cheaper Is It to Drive on Electricity?" Energy.gov. Department of Energy, 10 June 2013. Web. 14 July 2013. <http://energy.gov/articles/egallon-how-much-cheaper-it-drive-electricity>.

(30) Loiseau, Justin. "InvestorCenter." DailyFinance.com. N.p., 21 June 2013. Web. 15 July 2013. <http://www.dailyfinance.com/2013/06/21/pump-vs-plug-the-true-cost-of-electric-vehicles/>.

(31) Anair, Don, and Amine Mahmassani. "Electric Vehicles' Global Warming Emissions and and Fuel-Cost Savings across the United States." State of Charge. Union of Concerned Scientists, June 2012. Web. 14 July 2013. <http://www.ucsusa.org/assets/documents/clean_vehicles/electric-car-global-warming-emissions-report.pdf>.

(32) "Tax Breaks Available for Taxpayers Who Purchase Qualified Plug-In Electric Vehicles." IRS, 24 Apr. 2009. Web. 17 July 2013. <http://www.irs.gov/uac/Tax-Breaks-Available-for-Taxpayers-Who-Purchase-Qualified-Plug-In-Electric-Vehicles>.

(33) "Electric Car Costs vs Gasoline Cars vs Hybrids." CarsDirect. N.p., 8 Mar. 2012. Web. 10 July 2013. <http://www.carsdirect.com/car-pricing/new-electric-car-costs-vs-standard-gasoline-vehicles>.

(34) "Electric Vehicles." Sullivan Solar Power, n.d. Web. 15 July 2013. <http://www.sullivansolarpower.com/solar-power/electric-vehicles>.

(35) "National Average Prices." AAA's Daily Fuel Gauge Report. AAA, n.d. Web. 17 July 2013. <http://fuelgaugereport.aaa.com/?redirectto=http://fuelgaugereport.opisnet.com/index.asp>.

(36) "US Average Retail Price of Electricity." US Average Retail Price of Electricity (Monthly, US $\phi$ per Kilowatthours). YCharts, n.d. Web. 15 July 2013. <http://ycharts.com/indicators/us_average_retail_price_of_electricity_total>.

(37) "Fuel Economy." www.fueleconomy.gov. United States Department of Energy, n.d. Web. 15 July 2013. <http://www.fueleconomy.gov/>.

(38) LeSage, Jon. "Long-term Maintenance Costs Show Benefit of Electric Vehicles over ICEs." AutoblogGreen. N.p., 17 Dec. 2012. Web. 13 July 2013. <http://green.autoblog.com/2012/12/17/long-term-maintenance-costs-show-benefit-of-electric-vehicles-ov/>.

(39) Lavelle, Marianna. "How to Compare the Cost of Electric and Gas Cars." The Great Energy Challenge. National Geographic, 1 Oct. 2012. Web. 14 July 2013. 
<http://www.greatenergychallengeblog.com/2012/10/01/how-to-compare-the-cost-of-electric-and-gas-cars/>.

(40) Plumer, Brad. "The Social Cost of Carbon Is on the Rise." The Washington Post. The Washington Post, 06 June 2013. Web. 6 July 2013.

<http://articles.washingtonpost.com/2013-06-06/business/39789409_1_carbon-dioxide-emissions-obama-

administration>.

(41) "How Much Carbon Dioxide (CO2) Is Produced per Kilowatt-hour When Generating Electricity with Fossil Fuels?" Frequently Asked Questions. U.S. Energy Information Administration, 13 June 2013. Web. 13 July 2013. <http://www.eia.gov/tools/faqs/faq.cfm?id=74>.

(42) "Emissions from Hybrid and Plug-In Electric Vehicles." Alternative Fuels Data Center:. U.S. Department of Energy, n.d. Web. 14 July 2013. <http://www.afdc.energy.gov/vehicles/electric_emissions.php>.

(43) "Cars, Trucks, \& Air Pollution." Clean Vehicles. Union of Concerned Scientists, n.d. Web. 16 July 2013. <http://www.sciencedirect.com/science/article/pii/S136192091000146X>.

(44) Weinstock, Lewis, Nealson Watkins, Richard Wayland, Richard Baldauf, Jeffery R. Brook, Ilan Levy, and Cristian Mihele. "Near Road Monitoring." Environmental Managers July 2013: 7+.

(45) Kantor, Ivan. "Air Quality and Environmental Impacts of Alternative Vehicle Technologies in Ontario, Canada." International Journal of Hydrogen Energy 35.10 (2010): 5145-53. Print.

(46) "2 Million Deaths a Year Could Be Due to Air Pollution." Health. FOX61, 12 July 2013. Web. 15 July 2013. <http://www.myfoxchattanooga.com/story/22824894/2-million-deaths-a-year-could-be-due-to-air-pollution-study>.

(47) "UK Study Finds Electric Cars Can Reduce Urban Pollution." EVWORLD.COM: The 21st Century Future in Motion. N.p., 14 June 2013. Web. 18 July 2013. <http://evworld.com/news.cfm?newsid=30499>.

(48) Makinen, Julie July. "Study Links Heavy Pollution in China to Lower Life Expectancy." World Now. Los Angeles Times, 08 July 2013. Web. 15 July 2013. <http://www.latimes.com/news/world/worldnow/la-fg-wn-china-pollution-life-expectancy-20130708,0,795430.story>.

(49) Wing, Edward. "Pollution Leads to Drop in Life Span in Northern China, Research Finds." Asia Pacific. The New York Times, 8 July 2013. Web. 16 July 2013. <http://www.nytimes.com/2013/07/09/world/asia/pollution-leads-to-drop-in-life-span-in-northern-china-studyfinds.html $>$.

(50) Sunderland, Faye. "UK Trial of Electric Cars Proves They Are Greener." The Green Car Website, n.d. Web. 15 July 2013.

<http://www.thegreencarwebsite.co.uk/blog/index.php/2013/06/13/uk-trial-of-electric-cars-proves-they-are-greener/>.

(51) Brady, John. "Travel to Work in Dublin. the Potential Impacts of Electric Vehicles on Climate Change and Urban Air Quality." Transportation research. Part D, Transport and environment 16.2 (2011): 188-93. Print.

(52) "Electricity Generation and Pollution." Air Quality. Environmental Defense, n.d. Web. 16 July 2013. <http://www.science.smith.edu/ jcardell/Courses/EGR325/Readings/ElecPollution_EnvDef.pdf >.

(53) Foreman, J. C. Intelligent Power Management for a Solar Parking Structure for Plug-in Electric Vehicles., 2011. Print.

(54) Thomason, Mark. "The Solar Powered, Electric Vehicle Charging Station at the University of Central Florida." N.p., Apr. 2010. Web. 15 July 2013.

(55) "Mayor Coleman Unveils New Solar-powered Electric Car Charging Stations in Como Park, First of Their Kind in Minnesota." City of St. Paul, MN. N.p., n.d. Web. 14 July 2013. $<$ http://www.stpaul.gov/index.aspx?NID=4934>.

(56) "The Solar Station, Lane Community College." SOLARC: LCC Solar Station - Solar Powered Electric Vehicle Charging Stations. N.p., n.d. Web. 13 July 2013. <http://www.solarc-ae.net/projects/photovoltaic/solarstation.html>.

(57) "Electric Vehicle Infrastructure." Western Michigan University, n.d. Web. 15 July 2013. <http://www.wmich.edu/sustainability/projects/electric-vehicles>. 
(58) Danko, Pete. "Electric Vehicles at Michigan Campus Run on Solar Power." Midwest Energy News. N.p., 12 June 2012. Web. 15 July 2013.

<http://www.midwestenergynews.com/2012/06/12/electric-vehicles-at-michigan-campus-run-on-solar-powe/>. 